
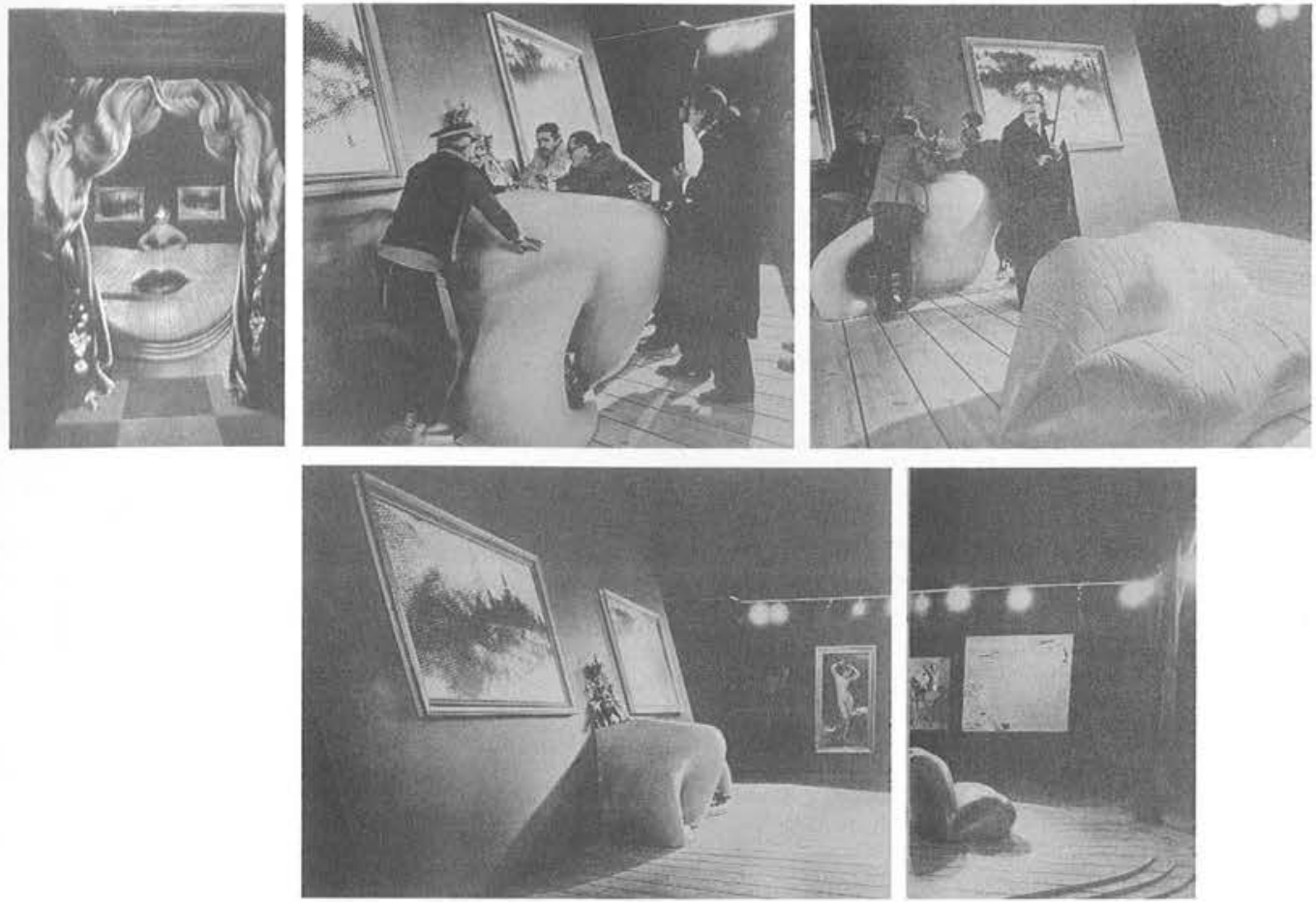

Mae West print (1934-35).

Assembling the apartment.

(Ramón Gómez de la Serna, Dali)

Mae West Apartment.



\title{
RE-VISITING MAE WEST'S FACE
}

Gordana Kostich-Lefebvre 
Ljudskoga lica i zvezdanog neba nikada se covek nagledao ne bi.

(One never beholds enough of human face and starry heaven.)

$$
\text { -Ivo Andric, "Lica, predeli" ("Faces, landscapes") }
$$

Note

Unless otherwise noted, images are from The Arcimboldo Effect: Transformations of the Face from the Sixteenth to the Twentieth Century.

Dali's famous gouache on printed paper from $1934,{ }^{1}$ Face Of Mae West Which May Be Used As A Surrealist Apartment, was realised forty years later as an "apartment" in Dali's Theatro-Museo, in his native Figueras. Constructed under Dali's direction by the Catalan architect-designer Oscar Tusquest, the Figueras piece consists of furnishings for a rather stretched, semi-enclosed space which needs to be viewed through an entraordinary observation point, a key(hole) to the face on the ground. Unfortunately, this spatial portrait and its decoder (vue eclarté) have never been presented as a two-part installation. This myopia needs to be corrected first.

If visitors were "ordinary" passers-by - that is, not already familiar with the "portrait," and not looking for it - the face would be concealed from them, and revealed only though a very particular "point of view." A viewer could certainly recognize the famous lip-shaped, red sofa, ${ }^{2}$ the most sensual of all sofas, and could even sit on it, but would not be able to immediately put it together with the rest of the facial features, which are separate objects apparently scattered around. The floor is slightly inclined. What would fit into the portrait as "blond bangs" is a suspiciously ragged carpet, which indeed draws attention as something out of its proper place, wherever that place could possibly be. A visitor's passage or hallway divides the "room" from a rectangular pedestal of table height, set across from, and at the orthogonal axis to the "sofa." A hoofed, stuffed animal - if my memory doesn't betray me, a single-humped camel - is placed upon the pedestal in an "en passant" position to the face fragments in the room, crossing Mae West's "neck," so to speak. On both sides of the pedestal, from the front and at the back of the camel, steps lead up the platform and a narrow space is left "behind" the sculpture, just enough for a person to stand and traverse it. Somewhere around the middle of the animal's belly there is a suspended speculum. It is only after the "speculant" climbs up from the side of camel's face, stops and bends halfway to look through a concave lens, ${ }^{3}$ that the object reveals itself to the eyes of the "mortal." Only together do the setting and a mirror make this face a spectacle. This is Dali's moment of initiation.

This work evokes a long and rich tradition of composed, encrypted and transformational representations. Thematically, it is close to aberrated portraits, "hidden" (subsumed) objects, and patchwork/puzzle compositions. Spatially, it is akin to two-part perspectival "experiments" of a Brunelleschian type; "scenographies"; architectural figurations in plan, landscape and/or garden assemblages; and even large-scale land designs visible only from the air. At first, references could be established with any of the above, but on closer inspection, nothing completely fits. Dali's piece seems truly independent from all of the above. So what is this aslant assamblage/ performance with a diva?

Surprisingly, nothing in Mae West Face installation or its operation is aberrated. ${ }^{4}$ Through the dimension of the "hidden face" invokes a composite portraiture of a kind that made Giovanni Arcimboldo and his humanoid creations ${ }^{5}$ influential far beyond refined Mannerism and an inspiration to twentieth century avant-garde artists. Breton, for example, considered Arcimboldo
1. The same year that the Surrealists as a group denounced Dali. gouache portrait, Dali made the first Mae West lips sofa, a wooden frame upholstered in dark and light "shocking pink," now much less known than the red lips sofa. He represented it in his 1937 chalk and gouache Birth of Paranoiac Furnishing.

3. Which might be called a "diminishing" lens, as opposed to a magnifying one.

4. What Dali aberrated this time was a traditional depth perception, as well as horizontal and vertical space expectations. By playing with our visual limitations, Dali teased and thwarted our spatial aptitude. He only extended the parameters within which we normally operate. There is a certain definite space within which we discern images and figures presented on the vertical surfaces. By considerably moving these limits Dali hid his creation. The face is a spatial composition: a horizontally designed, gigantic threedimensional sculpture, which could have been a part of a landscape or garden design were it in the open.

5. Mostly compositions of various species of the same class, they were also exercises in the art of classification, a real obsession of the mid-sixteenth century. Considerable attention has been paid to the (glamourised) musical chromatic notation that Arcimboldo supposedly used to correlate his paintings to music. See Tonino Tornitore, "Music for Eyes" in The Arcimboldo Effect: Transformations of the Face from the Sixteenth to the Twentieth Century, eds. Simonetta Rasponi and Carla Tanzi (Milan: Bompiani, 1987), 345-358. Leonardo's interest in chromatic music-as well as his organic sculpture/ shield of the head of Medusa which, although short-lived, was rather famousshould be seen in the same light.

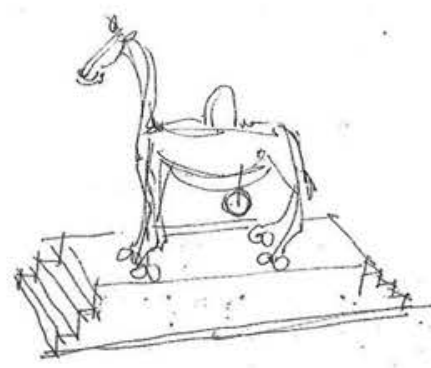

"Camel sketch" by author.
2. In 1936, a little more than a year after the 

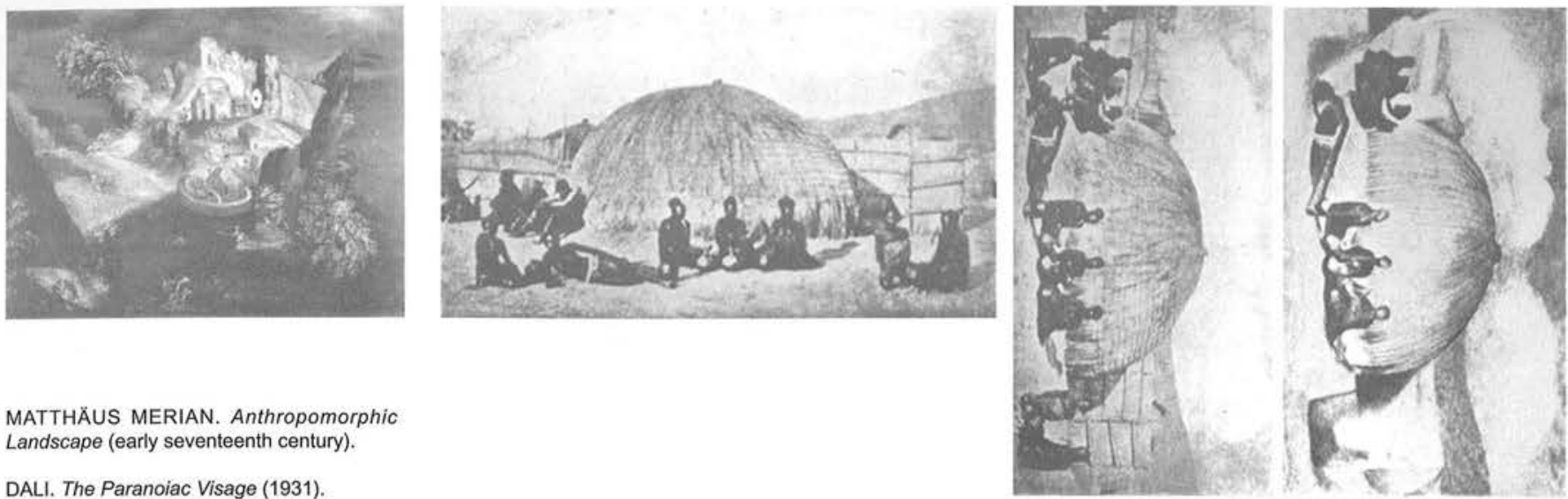

MATTHÄUS MERIAN. Anthropomorphic Landscape (early seventeenth century).

DALI. The Paranoiac Visage (1931). to be one of the masters and a precursor to the world of the imaginary and the marvellous. Surrealists were referring to the têtes composées ${ }^{6}$ long before the first monograph on Arcimboldo appeared in $1954 .{ }^{7}$ An anthropomorphic landscape by another Mannerist, Matthäus Merian (1533-1650), is curiously comparable to Dali's "ethnic" paysage polyvalently titled The Paranoiac Figure, an African village-scape within a giant female face whose "birth" as The Paranoiac Visage Dali originally presented in $1931 .^{8}$ Both fall into the category of human faces concealed in the landscape. ${ }^{9}$ Then the fact that, in order to access the picture of Mae West's face, it is necessary to raise a viewpoint twice - first of all by stepping onto the camel pedestal to discover the plane of depiction, and secondly "entering" the picture itself through the diminishing lens - places the installation on the level of "larger scale arts," although very far (below) from, for example, the ancient, mysterious Peruvian ground figures visible from thousands of feet above the ground; far even from the visions of bodies embedded in architectural plans ... but the principle is the same.

The theme of the convulsive face has its place within a general Surrealist exploration of illusionary and spatial visages, and this subject was regularly exploited, starting with De Chirico, ${ }^{10}$ but also by Ernst, Magritte, Delvaux, Duchamp and Man Ray. However Dali's work, more than anyone else's, abounds with symbolic and illusionary heads and faces. They are anthropomorphised and personalised spaces, often with mythological and cosmological dimensions. Dali divines rather than creates "hidden faces." His ability to initially perceive them, together with a deep persuasion that a face offers an entry to a set of conditions "behind" itself and, reciprocally, that the phenomena could be facialised (for example, in Dream [1931]; Anthropomorphic Echo [1937]; Sleep [1937]; Old Age, Adolescence, Infancy [1940]; and Melancholy [1942]) are the prerequisites for Dali's "facialisation." In this light it is quite natural that Dali titled his novel Hidden Faces, ${ }^{11}$ a novel "dealing with the development and the conflicts of great human passions ... the story of the war, and more particularly of the poignant post-war period." 12

Other apposite examples of Dali's metamorphic "facial" works are The Image Disappears (1938), a variation on Vermeer's interior metamorphosed into a "hidden" face; The Apparition of a War Scene on the Face of Lieutenant Deschanel (cover of Paris Match, 1954); the famous skull sculpted with bodies of four women, photographed by Phillipe Halsman (1954) and then retouched by Dali; Paranoiac-critical Conversion which was a Transformation of Antiques Magazine Cover into the Apparition of a Face (1974); Gala Contemplating the Mediterranean Sea which at Twenty Metres Becomes the Portrait of Abraham Lincoln (1976); ${ }^{13}$ and endless anamorphosed visages, including self-portraits on an empty-looking skin such as the one in Enigma of Desire. ${ }^{14}$

Philosophically, the Mae West installation seems to be firmly within a Lacanian system, 



and not only because the "object" is a face of the desirable American "cultural" icon from the thirties. It is a very clean uncanny, and the paradigm of a cleverly deconstructed object. It embodies many of elements figuring in Lacan's theory: camouflage and mimicry; the mirror; objet $a=$ agalma; luring; the gaze and the eye; the cathartic speculum; and sublimation. Dali's familiarity with Lacan's writings has often been emphasised and Lacan's "influence" on Dali is deduced from their acquaintance and the role of the paranoiac within Dali's system. Definitely, Lacan knew Dali's work. ${ }^{15}$ Taking into account their common interests in Freud, in the phenomenon of vision and the laws of optics and in painting, it is not surprising that there should have been an exchange between their respective systems. Mae West's Face requires a sharpening of the (scopic) vision, lying as it does between the large scale and the "readable," just across the threshold of the normally perceptible, merely but wittily hidden in front of "our noses." It is easy and convenient (perfectly suited) to interpret it in Lacan's terms where Dali's visions are already incorporated.

With regard to representational aspects, there is a considerable conceptual difference between facialised landscapes, heads sitting on the open ground and "faced" interiors. The facial landscapes as painted by Giorgione and Dürer are an extension of the recognition of "playful figurativeness of nature."16 Less well-known Arcimboldan "face-scape" woodcuts underline the interplay between the "natural," or the existing condition on one hand, and the real or possible manmade intervention on the other, rather than being illustrations of some portraiture both created and discovered "by chance." Volumetric "heads on the ground," such as Ork of Bomarzzo, Pirro Lighorio's anthropomorphic catharsis of the Entrance to Hell motif, like Le Corbusier's "facial five points" reveal a great tension with the chthonian from which they seem - painfully, and unsuccessfully - to attempt to gain independence. That is the case of anti-Antheus. A "faced" interior, in comparison, is completely unnatural, exclusively artificial. To phrase it better, it is utterly independent from nature's whim and under the full control of its creator. Paradoxically, to facialise an interior means to externalise it. An ephemeral facial epidermis envelops furnishings inside the dwelling, where a nose could become a hearth, the eyes landscape depictions framed on the wall and the lips a rosy love seat. Does this still resonate with a more traditional building/body analogy, where the breath is the vital force and the hearth coincides with the classical breathing heart or soul, ${ }^{17}$ windows are the eyes and the entrance is the mouth? The analogy is still possible although across the threshold, just behind the traditional mouth/entrance where the whole face-interior occurs, making room for the inner face. In the case of Mae West's Face, this transgression hinges on the fullness and startle of the pink-lipped love seat.

The access into an interior face - as opposed to the access to the interior through the faceinteriorising, and the face-interior are strung together beyond Lacan.
DALI. Study for The Image Disappears, in which a portrait in semi-profile appears in a "Vermeer" scene. (Robert Descharnes, Salvador Dali: The Work, The Man

DALI. The Endless Enigma (1938).

DALI. Ruin with the Head of Medusa and Landscape (1941).

Dali's portrait from the Extension of the Museo Dali. (Penny McGuire, "Surreal Collage," Architectural Review)

Original pink lips sofa for Edward James. (Robert Descharnes, Salvador Dali: The Work, The Man)

14. Further well-known faces are The Great Paranoiac (1936); The Infinite Enigma (1938) and the related Apparition Of Face and Fruit Dish on a Beach (1938); Visage of War (1940); The Market with a Disappearing Face of Voltaire (1940); Apotheosis of Homer (1944-45); Galatea of the Spheres (1952); Birth of a Deity (1960); and Apparition of the Visage of Aphrodite of Cnide in a Landscape (1981). Dali's own enormous black and white face, displayed on a revolving panel, camouflages the elevator door at the top of the staircase of the Extension to the Museo Theatro Dali (1995) and is reflected in a multitude of mirrors which clad the walls of the staircase. Only unwittingly does Dali's face go beyond being a "symbol of Dali's egocentrism."

15. For example, Jacques Lacan, The Four Fundamental Concepts of Psycho-Analysis (New York: W.W. Norton \& Co, 1981), 87 8 , where he mentions Dali by name. There are other, more general "artists" statements in the book where Lacan could have had Dali in mind.

16. That is, delight in the discovery of concealment and the subtlety of the figural. The phenomenon of "bearded clouds" - that is, the unintentional (non-artificial) figuration, described by Pliny (Natural Histories, ii.lxi) and re-admired during the Renaissance - has been lately discussed by Hubert Damisch in Théorie du nuage: pour une historie de la peinture (Paris: Éditions du Seuil, 1972).

17. The Greeks believed the seat of vital breath to be somewhere within the tight tissue of the heart and lungs. The Romans placed it in the whole chest (pectore): see R. Onians, "The Organs of Consciousness" and "The Stuff of Consciousness" in The Origins of European Thought (Cambridge: Cambridge University Press, 1991), 23-66. The parallel between altar, hearth and this essence of life was a commonplace in classical thought. 